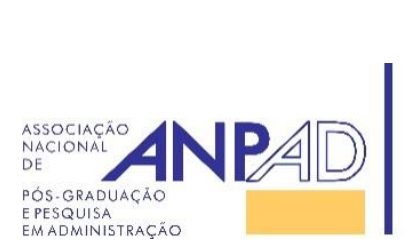

Disponível em

http://www.anpad.org.br/rac

RAC, Rio de Janeiro, v. 20, n. 6, art. 4, pp. 715-732, Nov./Dez. 2016

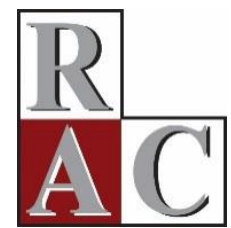

\title{
Geographical Indication Re-signifying Artisanal Production of Curd Cheese in Northeastern Brazil
}

Simone de Lira Almeida ${ }^{1}$ Fernando Gomes Paiva Júnior ${ }^{1}$

Carlos Costa ${ }^{2}$ José Roberto Ferreira Guerra ${ }^{1}$ IMED - Faculdade Meridional $^{2}$

Artigo recebido em 10.11.2015. Última versão recebida em 30.05.2016. Aprovado em 03.06.2016. Publicado online em 26.08.2016. 


\title{
Resumo
}

A acirrada competição de mercado e o crescente padrão de exigência dos consumidores em relação à qualidade têm estimulado organizações a buscarem certificações para diferenciar produtos e serviços. Um tipo de certificação que vem recebendo atenção de instituições interessadas no agronegócio é a Indicação Geográfica (IG). O significado de um artefato cultural, como o queijo coalho, não está no produto em si, mas nas relações que se estabelecem com quem o produz ou com quem o consome, com destaque para a interrelação dessas práticas de produção simbólica. Este estudo visa compreender como o processo de IG significa a produção artesanal de Queijo Coalho, agregando valor ao produto e tornando-o competitivo. Por meio da análise do discurso, foi possível comparar os significados culturais do queijo na sua forma original e naquela delineada pelos produtores que integram a Associação de Certificação do Queijo Coalho (CQP). Os resultados revelam que inovações advindas do processo de obtenção da IG têm ajudado os produtores da CQP na resignificação da sua produção artesanal, já que melhorias têm sido percebidas no processo produtivo, tanto na dimensão material do alimento, como no que se refere a sua dimensão simbólica.

Palavras-chave: produção simbólica; indicação geográfica; queijo coalho.

\begin{abstract}
Fierce market competition and growing consumer demand for quality have spurred organizations to seek certification as a way of differentiating their products and services from those of competitors. Geographical Indication (GI) is a type of certification that has received attention from agribusiness. The significance as a cultural artifact (e.g., locally-produced curd cheese) does not lie in the product itself, but in the relationships that are established between those who produce it and those who consume it, thereby highlighting the interrelationships of these symbolic production practices. This study seeks to understand how the process of GI certification has conferred new meaning on (re-signified) artisanal production of curd cheese in rural parts of the Brazilian state of Pernambuco. GI adds value to the product, making it competitive. Discourse analysis enabled comparison of the cheese's original cultural meanings with those outlined by Curd Cheese Certification Association (CCCA) member-producers. Certification-driven innovations have helped CCCA member-producers to re-signify their artisanal production, while providing a clear understanding of both the material and symbolic dimensions of improvements perceived to have occurred in the production process.
\end{abstract}

Key words: symbolic production; geographical indication; curd cheese. 


\section{Introduction}

Fierce market competition and a growing consumer demand for quality have spurred organizations to seek certification, which, in addition to differentiating products and services, also enhances consumer confidence. Regardless of the type of certification, the seals obtained through such a process ensure that the certified product meets criteria imposed by a given regulatory agency (Kim, Song, \& Yeo, 2016).

Achieving certification may contribute to an expansion in product sales beyond their region of production, thereby reaching hitherto untapped national and international markets. In order to obtain a certification, it is necessary for the characteristics of the product, such as a cheese, to be evaluated to assess whether it meets certain standards (Vázquez-Fontes, Sanchez-Vera, Castelán-Ortega, \& Espinoza-Ortega, 2010). For artisanal goods, also termed natural products, Geographical Indication (GI) is a sort of certification that catches the attention of economic agents with an interest in agribusiness (e.g., specialists, managers, academics, consumers and government organizations).

Existing studies regarding GI have dealt with its conceptualization and legal aspects (Valente, Perez, Ramos, \& Chaves, 2012), its economic potential (Silva et al., 2013), its impact on territorial development (Vieira \& Pellin, 2015), on the quality of products (Niederle \& Gelain, 2013) and cases of development of this kind of certification (Tonietto, 2011). The present study, by contrast, investigates the meanings connected to artisanal production undergoing such a certification process, based on an epistemological Cultural Studies perspective (Hall, 2008; Johnson, 2006).

In the present study, the case of curd cheese production in rural parts of Pernambuco serves to illustrate that efforts to achieve GI registration should not be conceived only as a way to protect a culture threatened with disappearance in the face of market globalization, but rather as a way to strengthen or emphasize certain forms of production. This view of GI registration is predicated on the belief that the meanings of particular cultural artifacts are not only inherent in them, but also woven into the relationships between producer and consumer, and, as such, provide the underlying dimensions of culture as representation and regulation through the producer, consumer and attendant cultural processes (Du Gay et al., 2013; Hall, 2008).

Curd cheese is a typical food of the Northeast region of Brazil, where it has been produced for the past 150 years. It is considered a popular cultural product from this specific region (Almeida, Paiva, $\&$ Guerra, 2010). Curd cheese is considered a part of the heritage of the northeastern population of Brazil and it is present in the agenda of economic agents, such as farmers, public and private institutions. The product has its own social and economic characteristics and is strongly associated with northeastern cuisine, even described as identity food by Menezes (2011). Most of the production of curd cheese is manufactured by hand and homemade on small farms (Meneses et al., 2012).

This type of cheese is usually made from raw milk. Hygiene and microbiological safety do not form part of the standardization of curd cheese. Although some studies point out these negative aspects, curd cheese is an important food item in the day-to-day lives of families in the Northeast region of Brazil (Freitas, Souza, Oliveira, Angelo, \& Bezerra, 2009)

As cultural meanings are not only found in the tangible elements of the product, but are also socially constructed and imposed by means of different social interactions, the present study seeks to understand how the process of obtaining the geographical indication of rural Pernambuco re-signifies the artisanal production of curd cheese, adding value to the product and making it competitive in the marketplace. The present study was thus guided by the following research question: how does the process of geographical indication re-signify artisanal production of curd cheese? This entails definition of certain benchmarks, including constructs regarding symbolic production and GI that constitute the cornerstone of our analysis, as well as clarify the present discussion. 


\section{Theoretical Background}

\section{Symbolic production: the circuits of culture approach}

The study of theoretical-methodological circuits, through which cultural artifacts are produced, distributed and consumed (Paiva, Guerra, \& Almeida, 2012) has been approached from two different perspectives entrenched in British cultural studies traditions (Du Gay et al. 2013; Johnson, 2006). A cultural artifact's meaning exists neither in the item itself, nor in its tangible elements, but predominantly in producer-consumer relationships and cultural processes (e.g., representation and regulation) (Du Gay et al., 2013; Hall, 2008; Johnson, 2006). Since these meanings are socially constructed and assist in the conversion of products into subjectively meaningful goods, their assignment occurs exclusively at the time of production (Ravasi \& Rindova, 2008). However, as meaningful construction is a complex process, it is generated at the time of production and may not necessarily be stably transposed to other actors.

Circuit of production and circulation of subjective forms approaches to understanding relationships in production-distribution-consumption both suggest that these dimensions do not lose the individual characteristics responsible for changes of significance in the forms produced and consumed (Johnson, 2006). A cultural product such as curd cheese is therefore recognized as a representative form of the subjectivity of a group of active agents of production, and thereby becomes a product rich in meaning, highlighting the overlap between cultural production and capitalist merchandise.

Bringing together five distinct cultural processes - production, consumption, regulation, representation and identity - the circuit of culture perspective proposed by Du Gay et al. (2013) proposes that meanings attributed to cultural products are transitory results arising from a combination of processes. The mutual interactions of these processes generate varied meanings and unforeseen contingencies. Therefore, from this perspective the meanings of cultural products do not emanate directly from the artifact itself, but from the existing linkage between the five dimensions of cultural processes, thereby (re)establishing a cultural space in which the meaning is put into circulation, i.e., is created, modified and recreated.

Based on the studies of Du Gay et al. (2013) and Johnson (2006), we developed a theoreticalmethodological process to investigate the subjective and objective dimensions guiding the production of cultural artifacts (Table 1).

Table 1

Working Definitions of Dimensions of Symbolic Production Employed in Defining Subjective and Objective Dimensions Guiding the Production of Cultural Artifacts

\begin{tabular}{|c|c|c|}
\hline Dimension & Category & Definition \\
\hline \multirow[t]{3}{*}{ Subjective (Abstract) } & $\begin{array}{l}\text { Benchmark } \\
\text { of Senses }\end{array}$ & $\begin{array}{l}\text { Subjective, socio-cultural and political aspects responsible for } \\
\text { building common meanings through which actors interact. }\end{array}$ \\
\hline & Lived Culture & $\begin{array}{l}\text { Aspects of producers' subjectivity with regard to their private } \\
\text { lives. }\end{array}$ \\
\hline & Work planning & $\begin{array}{l}\text { Designed to organize groups and put together the capital to } \\
\text { produce the forces and conditions of production. }\end{array}$ \\
\hline \multirow[t]{2}{*}{ Objective (Concrete) } & $\begin{array}{l}\text { Technical } \\
\text { Infrastructure }\end{array}$ & $\begin{array}{l}\text { Condition of materials involved in the production of cultural } \\
\text { artifacts. }\end{array}$ \\
\hline & $\begin{array}{l}\text { Social Relationship of } \\
\text { Production }\end{array}$ & $\begin{array}{l}\text { Manner of producers' association with one another and with } \\
\text { the other agents involved in the production of cultural goods. }\end{array}$ \\
\hline
\end{tabular}


The subjective or abstract dimensions (Table 1) are related to the action of the symbolic goods produced in the context of close relationships with peers. This dimension addresses the fact that cultural production includes private and subjective aspects guiding the construction of the reality shared by participants of a given group (Johnson, 2006). For Hall (2008), this type of production reflects a benchmark of senses and ideas underpinning the meanings shared by the cultural producer's action group. The categories belonging to this dimension are thus related to the need to understand cultural production through a conceptual framework that analyzes the system, not only strictly according to market forces, but also in political, social and symbolic terms.

Guiding the subjective, social and political dimensions shared by peers, the benchmark of senses (micro-perspective) represents the aspects responsible for ordering the construction of meanings among actors involved in a common project (Johnson, 2006). In turn, cultural life (macro perspective) demarcates the articulation between individual trajectories and the performance of the producers in the sector, culminating in a kind of working relationship representative of the particular history of these individuals (Scherer \& Jackson, 2008).

Beyond merely subjective aspects, the objective or concrete dimension is pervaded by goals and concrete components of social reality (Johnson, 2006). Work planning presents the forms encountered by producers themselves in organizing and articulating the social, economic and cultural capital interwoven into their operations. Scherer and Jackson (2008) point out that such formats tend to break away from business logic, resulting in more organic management and labour models.

Technical infrastructure constitutes the conditions of production available to producers in developing their projects. Differences between such technical conditions are indicative of economic and political disparities (Scherer \& Jackson, 2008). Finally, the social relations of production address the shapes encountered by producers in establishing relationships among themselves and with other agents of production when developing specific cultural goods. Categories included in both dimensions are therefore related to the need to understand the manner in which the production of cultural artifacts develops. This is achieved through a conceptual framework that includes this production, not only in purely mercantile or industrial terms, but also with respect to the logic-of-structures creation of senses discernible as they are interpreted and experienced (Beltrán \& Miguel, 2014).

The composition of the theoretical framework is adjusted according to the process of dialogue (interview) involved in obtaining field data, some categories being adapted and/or merged into others, thereby avoiding the duplication of concepts (Table 1).

\section{Geographical indication}

By associating them with natural and cultural aspects, GI promotes both the differentiation of food products and highlights their unique regional features in terms of the region of origin's organizational and technological capacities (Vieira \& Pellin, 2015). In Brazil, GI is governed by Industrial Property Law (Lei $\mathrm{n}^{\circ} 9.279,1996$ ), whereas internationally it is recognized through agreements on aspects of intellectual property rights under the World Trade Organization's Trade Related Aspects of Intellectual Property Rights.

Brazilian law (Lei $\mathrm{n}^{\circ}$ 9.279, 1996) vaguely defines GI as a geographic indication or designation of origin, limiting itself to defining appropriate seals of origin. Two kinds of protection for agricultural products and services are designated: indication of origin (IP) and designation of origin (DO), the latter designating a product whose characteristics are linked exclusively to the natural and societal environments of its production (Lei $\mathrm{n}^{\circ}$ 9.279, 1996).

Unlike trademarks or patents assigned to a single individual or organization, GIs have a character of collective law protecting a group of individuals. To obtain GI certification, small producers must not only improve production processes, but also organize collectively to create and maintain norms identifying the product to be certified (Kim et al., 2016; Vieira \& Pellin, 2015). 
Changes in artisanal production of curd cheese through GI-driven process innovations are not only limited to the product's tangible attributes, but also relate to the product's symbolic dimension, which are two inseparable quantities (Hall, 2008). The symbolic aspect of the curd cheese production process is therefore expected to allow the product and its producers to differentiate themselves in the market.

Unlike studies applying a realistic paradigm to GI, we sought to apply an epistemic contextualism (EC) perspective, viewing the recovery of artisanal curd cheese production not only as a way to reclaim an authentic product - a naive concept of global dynamics pervading contemporary society - but also as a legitimate practice to strengthen or emphasize cultural meanings that generate interest in the product. While most traditional researchers interpret GI registry as a way of protecting a culture at risk of extinction, those following an EC interpretation view traditional practices as products that incorporate historical and social aspects during their transmission across generations. They are therefore not immutable, although they retain elements that characterize them as traditional. Such elements of tradition "can therefore be altered to address different practices and positions, thereby acquiring new meanings and relevance" (Hall, 2008, p. 243).

\section{The dairy sector in Pernambuco State}

Of major Brazilian states, Pernambuco has seen the sharpest rise in milk production over recent years, increasing by $173 \%$ from 1999 to 2008 , when it reached $0.73 \times 10^{9} \mathrm{~L} \mathrm{yr}^{-1}$ (Brazilian Micro and Small Business Support Service [Serviço Brasileiro de Apoio às Micro e Pequenas Empresas SEBRAE], 2010). In 2010, the roughly 10,000 milk producers in Pernambuco produced approximately $2 \times 10^{6} \mathrm{~L} \mathrm{~d}^{-1}$, making Pernambuco the eighth largest milk producing state in the country and the second largest in the northeast of Brazil (Brazilian Institute of Geography and Statistics [Instituto Brasileiro de Geografia e Estatística - IBGE], 2008). Representing R \$81 million per month this production is vital to the region's socioeconomic development. While qualifying for dairy product registration, most of this production comes from small family producers and serves for the production of traditional cheese (e.g., curd cheese) and butter (SEBRAE, 2010).

Milk production in Pernambuco state occurs principally in rural areas, particularly in the south (Figure 1), where rainfall exceeds that of other regions, particularly those to the west. This serves to promote pasture growth and, in turn, increases milk production. The productive potential of the locality is impressive: these areas alone currently account for $73 \%$ of the state's milk production (SEBRAE, 2010).

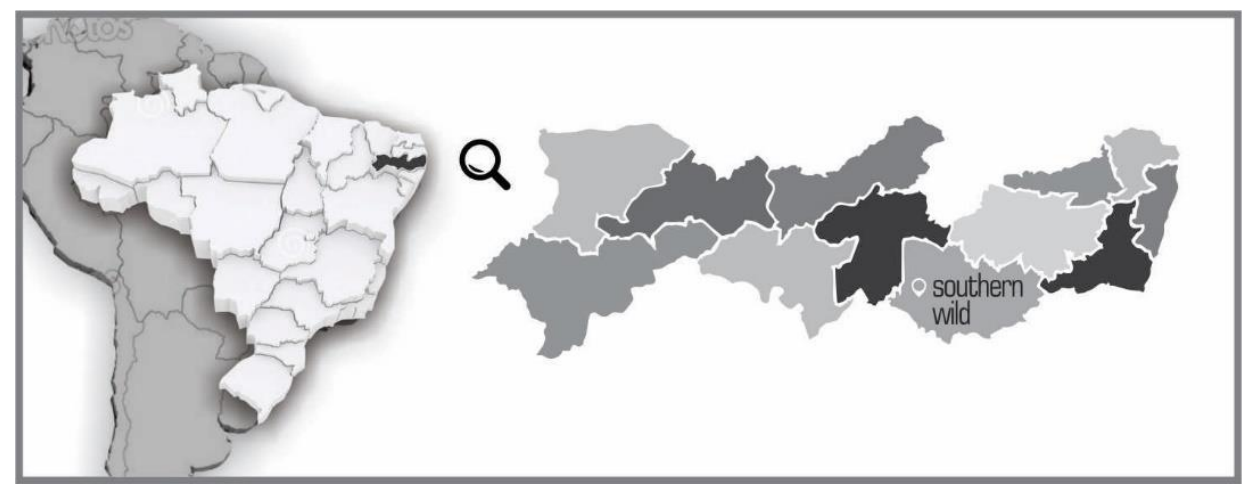

Figure 1. Dairy Production Regions in the Brazilian State of Pernambuco Source: Prepared by the authors.

In 2011, half of the state's 110 registered (i.e., holding a state inspection seal [EIS]) dairy production agribusinesses also produced artisanal cheese (Animal and Plant Health and Inspection Agency of Pernambuco [Agência de Defesa e Fiscalização Agropecuária de Pernambuco - ADAGRO], 2014). In contrast with its economic importance and popularity in the Northeast, curd cheese seldom meets minimum quality criteria for human consumption (Freitas et al., 2009). This results from the unregulated handling of animals before, during and after milking, a lack of monitoring of product quality 
standards (Vázquez-Fontes et al., 2000), the presence of pathogenic microorganisms due to poor sanitation, and local technical deficiencies in processing (Freitas et al., 2009). Aware of this situation, the Brazilian Micro and Small Business Support Service (SEBRAE) in partnership with the Pernambuco Institute of Technology (ITEP), have, since 2004, been working with a group of small-scale producers of handmade curd cheese to achieve a Rural Pernambuco GI designation from Brazil's National Institute of Industrial Property (NIIP).

\section{Method}

Given the interpretive nature of the present study, we adopted a qualitative approach based on the investigative discourse analysis guidelines outlined by Maingueneau (2015). In this kind of analysis, some facts are put forward, even though they are never fully secure, but rather in a state of unstable flow (Tonkiss, 2012). The choice of using discourse analysis as analytical support was based on the guidelines developed in the study by Du Gay et al. (2013). This highlights the fact that what is in circulation in society corresponds not only to products but also to sets of meanings and discourses that transform capitalist goods into artifacts whose symbolic component goes beyond the appearance of the product itself. The authors also note that an increasing number of economic processes are discursive formations. This shows that the economy also constitutes a cultural and historical phenomenon. This is dependent on modes of representation and the development of a shared language capable of articulating it within other spheres of society, allowing one to argue and intervene in the economic base. This fact requires a methodological framework that addresses the need to investigate the nature of these underlying dimensions which are, at times, silenced, and at other times present in the action and the constitution of the identity of persons working in the cultural production field (Barker, 2008; Davis, 2008).

The linguistic corpus was designed to maximize the variety of meanings associated with the production of curd cheese; it therefore includes the accounts of nine actors relevant to the process of obtaining a GI for the particular food product, including representatives of institutions such as SEBRAE, ITEP, CCCA, the Federal University of Pernambuco (UFPE), the Federal Rural University of Pernambuco (UFRPE) and the Brazilian Ministry of Agriculture, Livestock and Food Supply (MAPA), as well as people contextually linked to curd cheese production, but not directly linked to the product certification process. The group of respondents included: (1) a university professor with a Ph.D. in Education and a Masters in Management and Cooperative Development; (2) a dairy product technician of French origin working as an ITEP consultant; (3) an electrical engineer, who was ITEP chief technical officer from 1995 to 1998, during which period the PEDITEC emerged, as well as Coordinator of the Northeast Science Teaching Board (CECINE), at UFPE, from 2004-2010, where he coordinated several projects to support the development of the State's dairy basin; (4) a journalist specialized in gastronomy; (5) the director of artisanal cheese making and vice-president of CCCA; (6) the director of artisanal cheese making and president of CCCA; (7) a veterinarian and general manager of SEBRAE at a regional branch; (8) a Federal Agricultural Tax officer from the Agricultural and Development Support agency; (9) a veterinarian specialized in food quality control and SEBRAE consultant. The order of the interviewees described above corresponds to the numbering indicated after each interview excerpt.

This group of respondents was chosen based on the frequency with which they were mentioned in articles published on the websites of institutional partners connected with the GI curd cheese. The snowball method was applied to expand the pool of interviewees, i.e., each respondent was asked to suggest individuals having a significant relationship with the social practices under investigation.

The respondents were contacted by telephone and agreed to participate in the study. The interviews were conducted individually with the assistance of a semi-structured questionnaire and lasted 45 minutes on average. Nine interviews were face-to-face and two via Skype, although all were recorded with the prior consent of the respondents. 
The analysis drew on material from field interview transcripts, portions of which were categorized thematically into theoretical-methodological protocol categories (Table 1). The final composition of the theoretical and methodological framework was based on a survey of the material gathered in the different categories and sub-categories. The emerging categories were then arranged in such a manner that the findings gathered in the field were arranged in tables summarizing the meanings associated with different types of curd cheese production.

The validity and reliability of the data uses triangulation and rich description, as reported by Paiva, Leão and Mello (2011). The notion of multiple validity does not denote the absence of rules for conducting research. It means only that, instead of seeking a universal rule to be applied to all research, the existence of different rules for different methodological approaches must be recognized, which will lead us to account for realities in different ways (Barker, 2008).

Both these data attributes lie at the heart of ongoing efforts to interpret data, and thereby take into consideration the importance of creating a context for situating possible readers regarding the internal dynamics of this social group. One feature present in the interviews is the polyphony manifested by the participants, who, when talking about their own experiences, also reveal the perspective or vision of other agents in the sector.

\section{Results and Discussion}

As the meanings attributed to artisanal curd cheese production only make sense when compared to other systems of representation, the initial concern was to investigate how the formal and informal production of this culture-generating item are represented. The meanings of production generated by the CCCA's certification process served as a counterpoint to formal and informal modes of production.

\section{Informal meanings of artisanal curd cheese production}

Different interpretations of curd cheese production guide the actions of producers in rural Pernambuco. In the case of informal producers, cheese production does not represent a business opportunity in the dairy sector, but serves to exploit a surplus of household milk production through a simple production process. Table 2 summarizes the meanings found for this type of production.

Table 2

Subjective and Objective Dimensions Guiding the Informal Production of Curd Cheese in the Brazilian State of Pernambuco

\begin{tabular}{lll}
\hline Dimension & Categories & Meanings \\
\hline Subjective (Abstract) & Benchmark of senses & . Production process perceived as easy \\
& & . Limited technical ability \\
& . Family subsistence activity \\
& . Tacit knowledge \\
\cline { 2 - 3 } & Lived Cultures & . Motivated by surplus milk production \\
& . Absence of public authorities and regulators \\
\hline
\end{tabular}

Continues 
Table 2 (continued)

\begin{tabular}{|c|c|c|}
\hline Dimension & Categories & Meanings \\
\hline \multirow[t]{8}{*}{ Objective (Concrete) } & \multirow[t]{4}{*}{ Work planning } & Informal familial organization \\
\hline & & Domestic activity \\
\hline & & Homemade and handmade production \\
\hline & & Production w/o official standards or standardization \\
\hline & \multirow[t]{3}{*}{ Technical infrastructure } & $\begin{array}{l}\text { Traditional method of production w/o technological } \\
\text { innovation }\end{array}$ \\
\hline & & Simple and improvised equipment \\
\hline & & $\begin{array}{l}\text { Producer unprepared to produce cheese to quality } \\
\text { standards }\end{array}$ \\
\hline & $\begin{array}{l}\text { Social relations of } \\
\text { production }\end{array}$ & $\begin{array}{l}\text { No network of producers } \\
\text {. Individual action }\end{array}$ \\
\hline
\end{tabular}

Informal producers view curd cheese production as a family subsistence activity, so that both the intention and means of investment in the productive process are limited. Consequently, simple equipment and infrastructure available at the producers' residences are employed in initiating the manufacturing of cheese at the domestic level. One of the respondents, discussing how he began to produce curd cheese stated:

"I started generating an output from home, from a small room in my house. Then I moved operations to another room of the house, which was a room the previous owner had used as a confectionary. I adapted this room. I was getting better" (Interviewee 5).

Home production occurs in an improvised manner, without the aid of sophisticated tools or technological innovation. The organization of work is family-based and informal, and therefore has no specialized technical infrastructure (Menezes, 2011). Producers are therefore able to develop their activities only on the basis of tacit knowledge. In turn, the lack of technical knowledge and specialization amongst informal producers is reflected in a lack of standardization of the production process, which casts doubt on the quality of the final product.

Informal production is termed erratic and problematic, since it is free of both regulatory requirements, and any attempt on the part of the producers to establish quality standards (Meneses et al., 2012). On the other hand, a number of sources identified informal cheese manufacturing as an important source of livelihood for many farmers:

"curd cheese is very important because it is a product fraught with symbolism. Its production is well entrenched among the people here... I think that it is important, it allows a large number of families here in the State's dairy production region to survive; however, where things get complicated is from the point of view of hygiene control" (Interviewee 3 ).

"the production of milk and artisanal cheese, in this State, and even in neighboring States, is too large. It is unregulated, and therefore problematic from the point of view of public health, but this production is a fixture of the local farmer and sustains him" (Interviewee 3).

Given their precarious financial situation, cheese producers are unlikely to register their product when faced with the stringent production, marketing and consumption criteria involved in so doing. Registration is impossible, not only due to a lack of standardization, but also due to issues related to the quality of raw materials, particularly milk quality compromised by non-vaccinated cattle and poor milking hygiene (Freitas et al., 2009). As an alternative for solving such problems, CCCA producers advocate a more effective intervention of the State in assisting the formalization of small producers: 


\begin{abstract}
"The Government is very concerned about quality, right? But they just don't bother to solve the problem (of informal producers who produce to survive). Therein lies the question. So, the citizen who survives selling little boxes of cheese at the farmers' market will continue to do so, bringing product without the slightest qualification for being sold commercially, to be sold, not to be consumed. So, it is the Government's duty to empower these people, to train them or give small dairies and the means to organize so that they can conform and stop producing cheese the way they produce it now, you know?" (Interviewee $6)$.
\end{abstract}

Although regulation and inspection of the dairy sector has increased since the formation of ADAGRO in 2004, problems persist in the production and marketing of curd cheese. Informal producers wishing to circumvent government standards and continue selling their products often use counterfeit packaging. The focus on specific problems in the production of curd cheese is echoed in the construction of the identity of its producers. Compared with artisanal cheese producers in France, those of Pernambuco tend to be seen as ill-prepared, lacking in networking skills and behind the times in terms of adapting to new technologies:

"I think they (the producers) are ill-prepared - I'm saying generally, mostly -ill-prepared for the manufacturing process, such as the question of hygiene, ill-prepared for the process of organization. I think that's the point: they lack the technical skills and thus the market is prostituted. Why? Because these producers have no consciousness of the value the curd cheese has for the region and how they could benefit from it, if they get themselves organized, if they assimilated technology. There is no need for it to be advanced technology, just technology that is available in any industrial sector.... It's different, see, in France you see it's all controlled, completely standardized" (Interviewee 1).

The subjective and objective issues that establish the basis for the construction of meanings represent the worrying scenario with respect to the informal production of curd cheese. Recently, a similar approach has been adopted for understanding the meanings associated with formal industrial production of curd cheese.

\title{
Meanings associated with formal industrial production of curd cheese
}

Respondents' reported meanings regarding formal industrial production of curd cheese are summarized in Table 3.

Table 3

Subjective and Objective Dimensions Guiding the Formal Production of Curd Cheese in the Brazilian State of Pernambuco

\begin{tabular}{lll}
\hline Dimension & Categories & Meanings \\
\hline Subjective (Abstract) & Benchmark of senses & . Production routine driven by regulators \\
& . Technical skill extended \\
& . Managerial skill limited \\
& . Economic activity \\
& . Tacit and/or explicit knowledge \\
& . Perception of consumers interested in quality and origin \\
& of the product \\
\hline
\end{tabular}

Lived culture . Production motivated by need for business expansion.

. Concern with food security. 
Table 3 (continued)

\begin{tabular}{|c|c|c|}
\hline Dimension & Categories & Meanings \\
\hline \multirow[t]{11}{*}{ Objective (Concrete) } & \multirow[t]{5}{*}{ Work planning } & . Artisanal Production and/or industrial \\
\hline & & Formalization of enterprises \\
\hline & & Formal organizational structure \\
\hline & & Standardization instituted by external bodies \\
\hline & & Control over the production process \\
\hline & \multirow[t]{4}{*}{ Technical infrastructure } & . Professional qualification \\
\hline & & $\begin{array}{l}\text { Adequacy of the productive process standards legislation } \\
\text { in force }\end{array}$ \\
\hline & & Investment in infrastructure and equipment \\
\hline & & . Prior business management preparation by producer \\
\hline & \multirow[t]{2}{*}{$\begin{array}{l}\text { Social relationships of } \\
\text { production }\end{array}$} & $\begin{array}{l}\text {. Producers lack networking } \\
\text {. Individual performance }\end{array}$ \\
\hline & & Competition \\
\hline
\end{tabular}

For formal curd cheese producers, production is conceived of as a regulated economic activity. Formal production is motivated by a family producer's realization that business growth depends on his or her openness to the commercialization of the products at formal sales points (e.g., supermarkets and bakeries), where State or Federal Inspection Stamps are de rigueur.

Shifting from informal to formal production requires producers to acquire knowledge of legal requirements regarding food production and marketing but, when producers seek such information from regulators, the latter often provide confusing or contradictory information:

"I think Pernambuco's state legislation needs to improve a lot. They need to have clear definitions, something we do not have at present. If you get three ADAGRO tax officials and ask them separately what Pernambuco's state legislation is, you will see that each has a different opinion and has different issues with respect to the legislation" (Interviewee 5).

Despite the difficulties encountered in receiving adequate guidance from regulators, producers acknowledge the changes brought about by the formalization of the business. The acquisition of new equipment and improvement of the physical structure of the production unit are evident. Producers must therefore adjust the old production process to the standards of the legislation in force. For the interviewees, this investment in technical business infrastructure has a direct effect on improving the quality and presentation of the final product:

"After I registered my product, things started to change, both in production, such as with packaging, and with marketing. There was a very big change. I swapped the old wooden pan for a stainless steel one. I changed from carrying things any how ... to transporting them in a styrofoam box. To selling cheese in the market and starting to sell the cheese directly to the supplier, grocery stores, etc. So there was a pretty big change" (Interviewee 6).

Notwithstanding the law, the decision to invest in infrastructure and equipment for business expansion should be consistent with rational actions necessary to adapt the means of production to the resulting challenges. However, Scherer and Jackson (2008) argue that one of the problems with seeing organizational activities in such purely rational terms lies in the fact that the meanings that people give to their work often vary, even if their work consists of similar activities.

Explicit knowledge of the law, whether State or Federal, in addition to guiding producers with respect to the infrastructure required for the production of cheese and the attendant hygienic required conditions, includes questions about the receipt and handling of raw materials, as well as the preparation, 
standardization, conservation, packaging and transportation of the final product. However, the wide range of hygiene, sanitary and technical aspects under the inspection of regulatory bodies causes changes in production routines that interfere with the quality of the cheese produced.

Behavior patterns of individuals and the cultural features of social groups significantly influence the way individuals think and act in organizations (Ravasi \& Rindova, 2008). The individualism that, regardless of the mode of production, is a behavioral trait common to many of rural Pernambuco's curd cheese producers prevents producers from obtaining the benefits of a collective.

While problems with equipment and physical facilities tend to be minimized by the formalization of a business entity, difficulties remain regarding running the business efficiently and profitably. A producer who begins with homemade production may not be prepared to manage a business, even if this business has been formalized:

\footnotetext{
"They are extremely unprepared. So, if you come to them and ask how much it costs, for how much the product can be sold and what is their profit, certainly many of them won't be able to answer, don't you agree? So, those are the greatest difficulties. As for commercialization... they can't make contracts with some companies... When I'm saying this, I am talking about the small and medium producer ... The industry is already structured" (Interviewee 9).
}

The professional limitations of the curd cheese producer become even more apparent when the difference between artisanal and industrial producers is considered (Menezes, 2011). In the process of signification of formal production and differentiation of producers, industry entrepreneurs who work with pasteurized milk are more highly regarded than those working with raw milk (usually artisanal producers). Thus, the production techniques employed by industrial producers tend to be synonymous with investment in technology, innovation and professional development (Desmarchelier \& Szabo, 2008; Fryer \& Versteeg, 2008).

In an effort to strengthen their business in this context of production, some artisanal producers have been encouraged by government and non-government actors in the State of Pernambuco to initiate steps to acquire a GI.

\section{Meaning of curd cheese production: role of the certification association}

An attempt to understand the meanings of artisan production of curd cheese, in the context of obtaining a GI, not only tells a story about the design, manufacture, sale and consumption of the product, but more broadly, highlights the symbolic production process by which persons involved in the manufacture of curd cheese bring meaning to practices (Ravasi \& Rindova, 2008). Table 4 provides a summary of the meanings associated with curd cheese production by members of the certification association. 
Table 4

\section{Subjective and Objective Dimensions Guiding Certification Association Members' Production of Curd Cheese in the Brazilian State of Pernambuco}

\begin{tabular}{|c|c|c|}
\hline Dimension & Categories & Meanings \\
\hline \multirow[t]{8}{*}{ Subjective (Abstract) } & \multirow[t]{5}{*}{ Benchmark of senses } & $\begin{array}{l}\text { Production routine driven by regulators and the } \\
\text { Producers' Association }\end{array}$ \\
\hline & & . Conceptual and managerial technical skills \\
\hline & & . Economic and cultural activity \\
\hline & & Tacit and/or explicit knowledge \\
\hline & & $\begin{array}{l}\text { Perception of consumers interested in quality and origin } \\
\text { of the product }\end{array}$ \\
\hline & \multirow[t]{3}{*}{ Lived cultures } & . Production motivated by need for product differentiation \\
\hline & & . Concern with food security \\
\hline & & Appreciation of organoleptic aspects \\
\hline \multirow[t]{11}{*}{ Objective (Concrete) } & \multirow[t]{6}{*}{ Work planning } & . Artisanal production \\
\hline & & Mediation of the Association \\
\hline & & . Participation of people from different functional areas \\
\hline & & . Standardization instituted by internal and external agents \\
\hline & & . Participatory style of management \\
\hline & & . Structuring of supply chain \\
\hline & \multirow[t]{2}{*}{ Technical infrastructure } & $\begin{array}{l}\text { Support of research institutions and technological } \\
\text { development }\end{array}$ \\
\hline & & Technological improvement \\
\hline & \multirow{3}{*}{$\begin{array}{l}\text { Social relationship of } \\
\text { production }\end{array}$} & . Collective Action \\
\hline & & . Alliances and partnerships \\
\hline & & . Cooperation \\
\hline
\end{tabular}

The artisanal producers invited to participate in achieving GI status were already formalized before the work that went into creating the certification association. Formalization of the business and the keeping of records of curd cheese production are factors that can provide some characteristics of formal producers, setting them apart from informal producers. However, the subjective attributes and objectives arising from the process of formalization are not sufficient to promote the strengthening of handicraft production over industrial production.

Upon acquisition of the GI seal, artisanal producers who participate in this project are expected to differentiate themselves from the formal market. However, the achievement of this objective involves changes in abstract and concrete dimensions governing their production of curd cheese. As the majority of producers in the region are used to working individually, one of the main challenges faced by creators of the curd cheese GI certification project, was to attract and hold on to milk and cheese producers interested in operating collaboratively to set up the certification association (CCCA).

SEBRAE encourages artisanal producers to meet not only other cheese manufacturers but also milk suppliers, to ensure high quality throughout the production chain, as a way of meeting the demands of the National Institute of Industrial Property (INPI) in terms of building a collective organization, and to develop a vision of a shared effort, awareness and focused action.

Although it covers only a small group, the current membership of the CCCA sees such an associative organization to be a place where artisanal curd cheese producers can obtain specific 
membership benefits (Kim et al., 2016). To confront problems related to product quality and increase financial gains among association members, coordinated efforts on the part of dairy farmers and cheese producers are viewed as being the most effective form of organization:

"We have a lot of faith in this Association. Why exactly do we believe in it? Because, when it began to show results, right, within the cheese sector... it goes to show that if you are organized, such an organization works and works very well. In addition, being well organized leads to a better financial return, right? (Interviewee 6).

Since the absence of product standards constitutes an obstacle to the operation of the certification scheme, the CCCA started by setting desired quality parameters (e.g., flavor, color, size) for curd cheese produced in the region. The task of sensory characterization of curd cheese was carried out collectively, taking into consideration the opinion and experience of local producers concerning the production and consumption of this food product.

The first meeting to discuss the collective characterization of curd cheese led to the definition of an identity card for type $\mathbf{B}$ curd cheese based on ten organoleptic parameters: format, size, width, height, weight, color, general aspects, consistency, texture and flavor. Niederle and Gelain (2013) view this sort of negotiation around a specific setting of quality parameters for curd cheese as a way of generating commitment among different assessment bodies.

The standardization of curd cheese establishes the difference between cheese produced by the members of the CCCA and that of the other producers in the region, be they formal, informal, handcrafted or industrial. Far from being a paradox, the differentiation of curd cheese through its standardization constitutes a significant attribute for a product identity construct which usually suffers from the stigma associated with informal artisanal production.

The ability to standardize curd cheese has been stimulated by a concern for population health and safety and follows criteria which allow one to obtain the quality required by the client and facilitates international trade negotiations (Almeida et al., 2010).

The CCCA producers control the quality of raw materials by monitoring parameters of the chemical composition of fresh milk and hygiene inspections must take place systematically and meticulously in order to avoid the need for pasteurization. In formal craft production, the final quality of the product is linked to the quality of the raw material. Therefore, selecting good milk suppliers proves to be an institutionalized action that makes the certification of curd cheese particularly effective.

CCCA members rely on partnerships with various cooperating institutions (e.g., SEBRAE and ITEP), which provide technological solutions, thereby improving the cheese production process and making it possible to obtain GI certification. For Niederle and Gelain (2013), the development of a social network in which actors are involved in a new circuit of production and consumption is important for the institutionalization of the GI system.

With this social network's support, systematic innovation processes have increased artisanal curd cheese production. The genetic improvement of the herd, technological improvements and attention to health and sanitation concerns are parallel actions being developed by dairy experts, producers and development entities seeking to restructure the State of Pernambuco's dairy production region.

The act of ensuring recognition of the origin and the quality of agricultural products through GI represents a way of ensuring a reputation for quality and differentiating the goods in question. Niederle and Gelain (2013) suggest that strict sanitary control, traceability of the production process and the promotion of differentiated quality products will constitute criteria for opening international trade negotiations. Therefore, producers associated with the CCCA believe that obtaining the GI seal will add value to their product and, consequently, broaden opportunities for greater financial gains.

Du Gay et al. (2013) highlighted the fact that since production and consumption are not entirely separate, financial gains depend on the producer's ability to interpret the change of meaning which their 
products are subjected to during the period of consumption. For the authors, producers tend to develop practices relating to production and to the improvement of products based on assumptions they make regarding their product's consumers. One of the members of the CCCA indicated in his report that the consumer taken as reference by the Association is characterized as demanding and tends to worry about food quality and safety issues:

"The typical consumer is very demanding. He wants quality, and he is willing to pay a little more if the cheese is good quality. And we're going to offer, through the Association, this quality, this security that consumers need. He is now seeking safety. He does not question if he has to pay a little more, as long he has security in the product he is buying" (Interviewee 6).

The cheese makers that make up the CCCA, along with its partners, seem to understand consumers' desire to have access to safe foods, particularly in light of the uncertainties surrounding the production of white cheese, i.e., the presence on the market of products that are not genuine or of unknown origin. In the present scenario, these producers represent themselves as distinct from others, in an attempt to create an organizational culture capable of generating change in values and behavior of current and future associates.

Small producers in rural Pernambuco are carrying out this standardization process in the manner suggested by Kumar (2006) regarding standardization as a mark of mass production. In the case of the formal production of artisanal curd cheese, this helps us to understand that standardization should not be conceived only as a reflection of an administrative template, but also as an element attracting consumers who feel insecure as to the quality and safety of artisanal products.

\section{Conclusion}

The main conclusions take us back to the study's framework research question: how does the process of geographical indication re-signify artisanal production of curd cheese? In generic terms, formal production has been represented as a manager's commitment to providing safe and high quality food. This commitment is chosen rather than imposed, since compliance with the legislation that governs the production of milk and derivatives does not bear any warranties with respect to safety or quality.

Innovation in the curd cheese production process involves modifications to its subjective dimension, thus altering a significant aspect of a cultural artifact to enable the repositioning of the product in domestic and international markets. Improvements in the production process required to facilitate the registration of GI thus seem to symbolically mark handcrafted products in a positive manner. This repositioning is established by a symbolic differentiation between the artisanal producers and general industry producers. Namely, the actors involved in the certification process build cultural meanings linked to certain attributes, capabilities and forms of conduct to establish a positive sense for food produced from scratch, in order to position themselves in a distinct manner within a certain organizational field.

The transformation of the dominant meanings involves a process of struggle within and outside these organizations, since the directions assigned to artisanal cheese, in terms of its innovation process linked to GI registration, are not transferable to other instances of meaning in a fixed or stable way. The (re)signification of artisanal cheese has been stimulated by the introduction of incremental innovations in production, but it can only acquire a hegemonic character when the repertoire of meanings established by the institutions linked to the project of getting the GI is supported, shared and disseminated by actors positioned strategically in different parts of the production chain. Thus, changes in artisanal curd cheese production depend on shared policies being drawn up by the producers of the certification association, along with other producers, consumers, regulatory institutions and media agents.

One of the contributions of the present study lies in discussing the innovation process as a symbolic asset, while taking into account the political dimension of this phenomenon. By demarcating 
the power relations in the context of production of this commodity, one can catalyze the development of this innovative process or inhibit its action. This allows one to realize how limited our understanding would be if the innovation process was seen strictly from a perspective of technological improvements, tangible investments, research and development and patents.

Further studies could be conducted to understand the production of cultural artifacts in the context of the stages of movement of symbolic goods, such as consumption and representation. In all cases, we recommend the use of alternative methodologies, while maintaining the interdisciplinary approach necessary for understanding the production, distribution and consumption of symbolic goods within an inter-sectorial context.

With the assistance of cultural concept studies, we demonstrated, in this study, the need for a greater focus on the meanings assigned to a cultural artifact in terms of processes and innovation and the conflicts around their cornerstones. By focusing on the process of constructing the significance of a particular type of merchandise, the aim was to counter the econometric view at the heart of many studies of innovation, and, at the same time, reveal the relationships of consensus and dissent that pervade and affect the production of meanings of a product through the innovation process. This also proves to be a way by which to unravel the political and cultural means employed by the agents of innovation to alter their identity settings and to compete sensibly and powerfully in the market.

\section{References}

Agência de Defesa e Fiscalização Agropecuária de Pernambuco. (2014). Relação de estabelecimentos $\begin{array}{lcr}\text { com } & \text { S.I.E. } & \text { Retrieved } \\ \text { http://www.portais.pe.gov.br/c/document_library/get_file?uuid=4d0c5b }\end{array}$ from http://www.portais.pe.gov.br/c/document_library/get_file?uuid=4d0c5b66-80c6-4a46-9016$860 \mathrm{~d} 8813 \mathrm{e} 2 \mathrm{~b} 1 \&$ groupId $=19882$

Almeida, S. de L., Paiva, F. G., Jr., \& Guerra, J. R. F. (2010). A estratégia de internacionalização de negócios na perspectiva da tradução cultural: o caso da indicação geográfica no agronegócio. Revista Ibero-Americana de Estratégia, 9(2), 74-97. http://dx.doi.org/10.5585/riae.v9i2.1670

Barker, M. (2008). Analysing discourse. In M. Pickering (Ed.), Research methods for cultural studies (pp. 150-172). Edinburgh: Edinburgh University Press.

Beltrán, G. J., \& Miguel, P. (2014). Doing culture, doing business: a new entrepreneurial spirit in the Argentine creative industries. International Journal of Cultural Studies, 17(1), 39-54. http://dx.doi.org/10.1177/1367877912461906

Davis, A. (2008). Investigating cultural producers. In Pickering, M. (Ed.). Research methods for cultural studies (pp. 53-67). Edinburgh: Edinburgh University Press.

Desmarchelier, P. M., \& Szabo, E. A. (2008). Innovation, food safety and regulation. Innovation: Management, Policy \& Practice, 10(1), 121-131. http://dx.doi.org/10.5172/impp.453.10.1.121

Du Gay, P., Hall, S., Janes, L., Madsen, A. K., Mackay, H., \& Negus, K. (2013). Doing cultural studies: the story of the Sony Walkman (2nd ed.). London: Sage Publications.

Freitas, J. R., Filho, Souza, J. S., Filho, Oliveira, H. B., Angelo, J. H. B., \& Bezerra, J. D. C. (2009). Avaliação da qualidade do queijo coalho artesanal fabricado em Jucati-PE. EXTENSIO: Revista Eletrônica de Extensão, 6(8), 35-49. Retrieved from https://periodicos.ufsc.br/index.php/extensio/article/view/1807-0221.2009v6n8p35/11446. http://dx.doi.org/10.5007/1807-0221.2009v6n8p35

Fryer, P. J., \& Versteeg, C. (2008). Processing technology innovation in the food industry. Innovation: Management, Policy \& Practice, 10(1), 74-90. http://dx.doi.org/10.5172/impp.453.10.1.74 
Hall, S. (2008). Da diáspora: identidades e mediações culturais. Belo Horizonte: Editora UFMG.

Instituto Brasileiro de Geografia e Estatística. (2008). Produção da pecuária municipal. Retrieved from http://biblioteca.ibge.gov.br/visualizacao/periodicos/84/ppm_2008_v36_br.pdf

Johnson, R. (2006). O que é, afinal, estudos culturais? In T. T. da Silva (Ed.), O que é, afinal, estudos culturais? (pp. 9-131). Belo Horizonte: Autêntica.

Kim, Y.-J., Song, S.-Y., Yeo, J. (2016). The effect of geographic indication in advertising background pictures on product evaluation: the moderating role of familiarity. Asian Journal of Social Psychology, 19(2), 163-169. http://dx.doi.org/10.1111/ajsp.12117

Kumar, K. (2006). Da sociedade pós-industrial à pós-moderna: novas teorias sobre o mundo contemporâneo. Rio de Janeiro: Jorge Zahar.

Lei $n^{\circ}$ 9.279, de 14 de maio de 1996. (1996). Regula direitos e obrigações relativos à propriedade industrial. Retrieved from http://www.planalto.gov.br/ccivil_03/leis/L9279.htm

Maingueneau, D. (2015). Discurso e análise do discurso. São Paulo: Ed. Parábola.

Meneses, R. B., Cardoso, R. C. V., Guimarães, A. G., Góes, J. A. W., Silva, S. A., \& Argolo, S. V. (2012). O comércio de queijo de coalho na orla de Salvador, Bahia: trabalho infantil e segurança de alimentos. Revista de Nutrição, 25(3), 381-392. http://dx.doi.org/10.1590/S141552732012000300008

Menezes, S. S. M. (2011). Queijo de coalho: tradição cultural e estratégia de reprodução social na Região Nordeste. Revista de Geografia, 28(1), 40-56.

Niederle, P. A., \& Gelain, J. (2013). Geographical indications in Brazilian food markets: quality conventions, institutionalization, and path dependence. Journal of Rural Social Science, 28(1), 26-53.

Paiva, F. G., Jr., Guerra, J. R. F., \& Almeida, S. L. (2012). A dimensão pública da ação do empreendedor cultural na produção de cinema. Cadernos de Estudos Sociais, 27(1), 155-170.

Paiva, F. G., Jr., Leão, A. L. M. S., \& Mello, S. C. B. (2011). Validade e confiabilidade na pesquisa qualitativa em administração. Revista de Ciências da Administração, 13(31), 190-209. http://dx.doi.org/10.5007/2175-8077.2011v13n31p190

Ravasi, D., \& Rindova, V. (2008). Symbolic value creation. In D. Barry \& H. Hansen (Eds.), The Sage handbook of new approaches in management and organization (pp. 270-284). London: Sage.

Scherer, J., \& Jackson, S. (2008). Cultural studies and the circuit of culture: advertising, promotional culture and the New Zealand all blacks. Cultural Studies $<=>$ Critical Methodologies, 8(4), 507526. http://dx.doi.org/10.1177/1532708608321577

Serviço Brasileiro de Apoio às Micro e Pequenas Empresas. (2010). Boletim setorial do agronegócio: bovinocultura leiteira. Recife: Autor.

Silva, L. C. S., Kovaleski, J. L., Gaia, S., Back, L., Piekarski, C. M., \& Francisco, A. C. de (2013). Geographical Indications Contributions for Brazilian Agribusiness Development. African Journal of Agricultural Research, 8(18), 2080-2085. http://dx.doi.org/10.5897/AJAR12.2188

Tonietto, J. (2011, June). Vales dos Vinhedos and the development of geographical indications in Brasil. Anais of the Worlwide Symposium on Geographical Indications, Lima, Peru.

Tonkiss, F. (2012). Discourse analysis. In C. Seale (Ed.), Researching society and culture (3th ed., pp. 405-423). Londres: Sage. 
Valente, M. E. R, Perez, R., Ramos, A., \& Chaves, J. B. P. (2012). Indicação geográfica de alimentos e bebidas no Brasil e na União Europeia. Ciência Rural, 42(3), 551-558. http://dx.doi.org/10.1590/S0103-84782012000300027

Vázquez-Fontes, C., Sanchez-Vera, E., Castelán-Ortega, O., \& Espinoza-Ortega, A. (2010). Microbiological quality of artisan-made Mexican Botanero cheese in the central highlands. Journal of Food Safety, 30(1), 40-50. http://dx.doi.org/10.1111/j.17454565.2009.00188.x

Vieira, A. C. P., \& Pellin, V. (2015). As indicações geográficas como estratégia para fortalecer o território - o caso da indicação de procedência dos vales da uva Goethe. Desenvolvimento em Questão, 13(30), 155-174. http://dx.doi.org/10.21527/2237-6453.2015.30.155-174

\section{Authors' Profiles}

Simone De Lira Almeida

Rua dos Funcionários, s/n, Cidade Universitária, 50740-580, Recife, PE, Brasil. E-mail: simoneufpe.almeida@ gmail.com

Fernando Gomes Paiva Júnior

Rua dos Funcionários, s/n, Cidade Universitária, 50740-580, Recife, PE, Brasil. E-mail: fernando.paivajr@ gmail.com

Carlos Costa

Rua Senador Pinheiro, 304, Rodrigues, 99070-220, Passo Fundo, RS, Brasil. E-mail: carlos.costa1 @ gmail.com

José Roberto Ferreira Guerra

Rua dos Funcionários, s/n, Cidade Universitária, 50740-580, Recife, PE, Brasil. E-mail: j.roberto.guerra@ gmail.com 